\title{
RE-ANALYSIS OF A THEORY OF RIGHTS
}

\section{W. Jethro Brown}

The eminence of Sir Paul Vinogradoff, both as publicist and jurist, commands homage. Yet his recent article ${ }^{1}$ provokes comment if regarded as a contribution to juristic literature. The limitations of my outlook may be responsible; but I read with high expectation and concluded in mystification.

"Law is right taken objectively from the point of view of society, right is the personal conviction of men as to what is due." 2 The senterice baffles. One is impelled to ask, "Due by what test, standard or opinion?" If the answer is individual opinion, we have anarchy, not law and order. The concluding part of the paragraph seems designed to evade such conclusion. In so far as it succeeds it confuses, as far as legal science is concerned, the very distinction which the paragraph purports to expound. In a.modern society, Right in law is a complexus which a State will protect, as far as may be practicable in a world of imperfections. Personal conviction is irrelevant. Aliter, in morals, sociology, psychology.

"That the right should exist it must be claimed." Another mystification! The title of an unconscious legatee is by law none the less a right. The citizen of to-day lives within a system of legal rights which he accepts with the same complacency as he does night and day. Where a right is disputed, he may make a claim. Only by tedious process of psycho-analysis can the need for a "claim" be even suggested. But the realm of the sub-conscious self, of interest to the psychologist, is too remote for the jurist. Neither lawyer nor jurist needs to conjure in order to arrive at results which surprise, please or disconcert. To introduce a claim as a condition precedent of legal right is to assert what law ignores. Historically, rights may result from claims. Hence the above reference to psycho-analysis. A lawyer in search of proximate certitude asks for an analysis of legal relations which is something more than an appeal to possible historical origins.

A little later on we are told that a second stage in right is a declaration. That is to say, "a recognition by organised society that the claim is justified from the public point of view." Nous marchons. "Mais aussi sans génerositê." For the lawyer the public point of view is only of import in extremis. John Stuart Mill said that extreme cases test principle. Possibly. Juristic analysis is most helpful when it proceeds by reference to type. The conclusion is Westlake's. I humbly subscribe to it. Maitland, apropos of his own researches in legal history, once remarked to me on the danger of being too definite. But one may be so indefinite as merely to perplex. In The Study of Law and The Austinian Theory of Law I seek to recognise the fact that we

${ }^{1}$ The Foundations of a Theory of Rights (1924) 34 YALE Law JouRnad, 60.

${ }^{2}$ Loc. cit.

Loc. cit. 
do not live in a world of water-tight compartments. Most sciences have to reckon with the fact. The bio-chemist must know something of physics. The lawyer ought to know much about allied sciences; but the sciences need not be confused. The remark may seem irrelevant in view of Vinogradoff's footnote, "My aim is to examine the action between the judicial concept of right and the background of individual claims and social interests." But the article is entitled The Foundations of a Theory of Rights. A foundation is part of a structure, though not necessarily in surface view. An article on the foundation of a theory of rights, contributed to a journal of sociology or ethics, may escape from criticisms which are inevitable if the article be published in a Law Journal. To vary the metaphor, the student of a field of thought is distracted rather than helped if his mentor directs the vision outside the fence rather than within it. The existence of gaps in the fence has only a partial relevancy. The more helpful analogy is that of a tree whose roots are in the soil. The implicit criticism applies in my opinion to much of the juristic literature of to-day. An endeavor to be historically minded in the interpretation of law-an endeavor to which Vinogradoff has so greatly contributed-is laudable. One must even admit that a concept of Law's purpose may affect the view of Law's content. But in Jurisprudence, assuming definition by reference to type, the purpose should be a reasonable inference from law, not a mere ideal of the interpreter. The distinction between law and morals remains. Roscoe Pound's recent brochure, ${ }^{4}$ if one reads between the lines, expresses my meaning with an adequacy impossible within the limits of a single article. I even conceive that a lawyer of to-day would be better for knowing something of the revelations of latter day physics, providing always that he remembers that he is a lawyer.

General cultural outlook should bring a sense of proportion and a realisation of the importance of the spirit of law as contrasted with the mere letter. There is, however, a danger, as I tried to show in an article $^{5}$ of substituting caprice for principle in the actual administration of justice. Disordered subjectivity. The jurist should not encourage. Of course, he cannot build save on actualities. In a State where the administration of justice is dependent on the individual opinion of particular judges as to what is desirable or expedient in each particular case, Jurisprudence as I understand the term is not possible. But is the Anglo-American community in such a stage? I hope not. I believe not. I trust the Judge will continue, speaking of law in general, to be as objective as he can. That he will disregard personal preference, and even be steeled against the influence of what may chance to be, for the time being, the "public point of view."

Vinogradoff proceeds to say ${ }^{6}$ that the third element of right is
"Lazw and Morals (Ig24).
'Administ-ation of Justice in England: 1906 v. 1923 (1924) 33 YALE LAW
JouRNAL, 838.
'At p. 6r.


enforcement. Not, however, enforcability. "It is by no means uncommon that claims are regarded by Courts of justice as being justified but unenforcable." The case of judicial order for restitution of conjugal - rights is given as an instance. But surely such a right is "enforcable" by way of collateral proceedings for constructive contempt of Court. A cherry is none the less a cherry because two bites may be necessary. In any case one is emboldened to ask the question whether the so-called order for restitution of conjugal rights confers a right to consummation, or is designed to place an applicant in a strategic position from which things may be made uncomfortable for a recalcitrant. Just as a right under a contract is normally not an absolute right to production of goods or performance of services since the recalcitrant has the alternative of paying damages. Any "Foundation of a Theory of Rights" which ignores such facts is misleading. This is not barren abstraction, but concrete reality. The poverty of language may be pleaded alike by lawyer and jurist. By the jurist in a lesser degree. It has been said of woman, rightly or wrongly, that a more limited vocabulary than man's is more than compensated by an incomparably greater turnover. This is just not the sort of thing which I have in mind when I contrast lawyer and jurist. Both, however, have to realise that law is more than language. The distinction between "enforcement" and "enforcable." emphasised by Vinogradoff, appears to me an illustration of an endeavor to make legal analysis a generalisation from social phenomena, whereas legal science must ignore certain social phenomena. Further, statements of legal principle should be representations rather than generalisations of the world of things as they are. Generalisations which attempt to cover all possible contingencies recognised in law or existent in fact, are about as helpful to the lawyer in ordinary practice as trite moralities to the citizen perplexed as to the precise scope of his duty to his neighbor.

The attacks upon Ihering and Duguit ${ }^{7}$ include statements which I cannot discuss without being unduly discursive. I have expressed my opinion about the jurisprudence of M. Duguit in an article. ${ }^{8}$ I will only say here that in my view a book may be suggestive sociology and bad law. Even bad jurisprudence. Vinogradoff alleges of Hobbes and Austin ${ }^{9}$ that they did not recognise individual rights because individual man is an atom when compared with leviathan, "a sovereign wielding an overwhelming authority over an obedient community." Surely, a caricature. Austin's language is often infelicitous. His analysis of the concept of State is inadequate for to-day. But, to do him justice, we must concede that in his view the force of the State is the means of the protection of the rights of the individual. To amplify this statement would be to rewrite my excursus in The Austinian

'At pp. 62-64.

The Jurisprudence of M. Duguit (IgI6) 32 L: QUART. REv. I68.

- At p. 63. 
Theory of Laze. Especially excursus $E$ which is a consideration of some objections to the conception of positive law as State command. In that excursus I endeavor to do justice to the spirit of Austin's teaching. I conclude with the definition- "Law, as the term must be interpreted in legal science, is the organic totality of the rules relating to external human action, together with the associated systems of rights and duties. which those rules imply, affirmed by the State through official organs, maintained by the organized power of the State, and applied by the Courts of the State in the discharge of their judicial functions."

At page 64, Vinogradoff discusses the question whether certain fundamental rights and claims ought not to be treated as inherent in the nature of a free man and citizen. It is difficult for me not to feel that the very learned contributor is flirting with Naturrecht. The references on page 68 to Arlidge v. Local Government Board ${ }^{10}$ and Scott née Morgan and another $v$. Scott ${ }^{11}$ are unconvincing. As regards the former case, the appeal to "natural justice" might be cited to exemplify the lawyer in an occasional dilemma. Not typical. Not representative. The latter case is interesting as showing the importance which courts of law attach to the principle of public trial. One can acknowledge this importance without departing from the spirit of the teaching of Hobbes and Austin.

In conclusion, I crave permission to state that a disagreement from a learned writer on certain passages must not be taken to indicate wholesale lack of appreciation. With much that Vinogradoff says I humbly concur. May this be accounted unto me not only for righteousness but also for sanity! I deem it my misfortune that the matters of disagreement form the central features of this article. At the risk of repetition I desire to summarise the main purposes of the main article. I have in mind certain conclusions. ( $\mathrm{I}$ ) Although no lawyer could claim to be practical unless he is also theoretical, legal theory, whether expressed in law books or juristic literature, should keep in close touch with realities as envisaged by Judges. A reader who may be sceptical as regards the premise may be referred to Tilden's excellent books on lawn tennis. Or to expositions of the "tournament temperament." (2) A jurist is likely to be of real service to the lawyer in proportion as he keeps in constant view two things: the distinction between law and opinion (individual and collective); the fact that while every good law book is a contribution to legal science, juristic literature may only serve to dissipate or distract mental energy if it confuses cultural outlook with law itself-that which has to be interpreted and applied.

${ }^{20}[1915$, H. L.] A. C. 120, reversing [1914] 1 K. B. 160 .

[I [1913, H. L.] A. C. 417. 